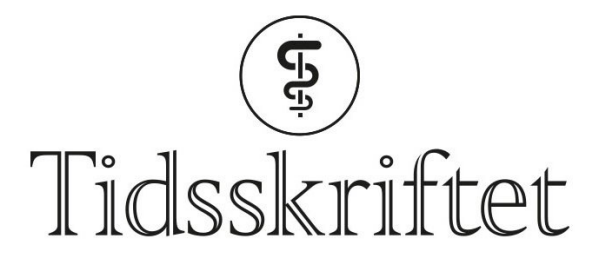

DEN NORSKE LEGEFORENING

\title{
DNA-endringer etter lange opphold i verdensrommet
}

FRA ANDRE TIDSSKRIFTER

HAAKON B. BENESTAD

Universitetet i Oslo

Lange romferder gir økt risiko for DNA-endringer og mulig økt risiko for kreft og arteriosklerose.

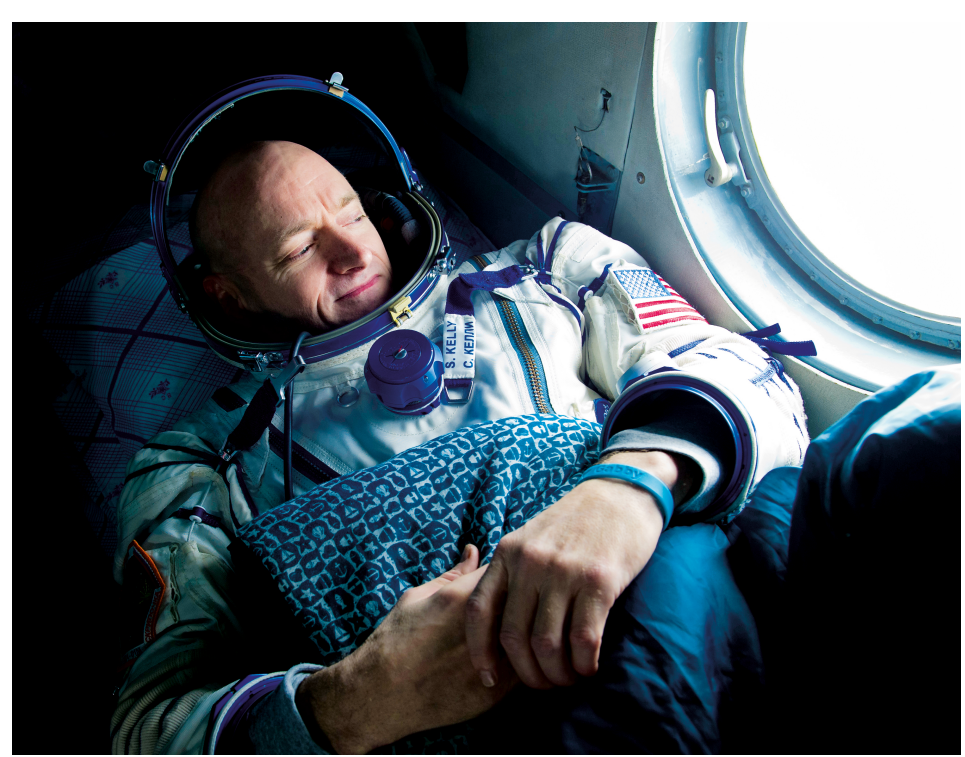

Astronaut Scott Kelly på vei hjem etter å ha vcert på romstasjonen. I 340 dager sammenlignet forskere fra NASA omhyggelig Kelly med hans jordbundne tvilling, Mark. Foto: NASA / NTB Scanpix

Ved eventuelle romferder til Mars og andre planeter vil astronautene bli utsatt for mikrogravitasjon, ioniserende stråling og andre stressorer, som støy, isolasjon og avbrutt døgnrytme - kanskje i årevis. Hittil har få astronauter oppholdt seg ute i verdensrommet $\mathrm{i}$ over ett år, men én av dem var med i NASAs tvillingstudie (1). Hans genetisk identiske tvillingbror var kontrollperson i et 25-måneders pilotprosjekt, der astronauten oppholdt seg på den internasjonale romstasjonen i ett år. Begge ble gjenstand for mange fysiologiske, biokjemiske, molekylærmedisinske og andre målinger før, under og etter romfarten.

Sammenlignet med sin tvillingbror hadde astronauten endret tarmmikrobiom og redusert kroppsmasse (vurdert som lavrisikoendringer), endret regulering av kroppsvæsker og kollagendannelse (vurdert som risiko av middels eller ukjent grad) og DNA-/kromosomforandringer i blodleukocytter, fortykket vegg i halsarteriene, øyebunnsforandringer og kognitiv svekkelse (vurdert som høyrisikofunn). 
Det er godt kjent at de beregnede stråledosene (146 millisieverts) kan gi genomskader. De tilsvarer 50 års naturlig bakgrunnsstråling på jorden og vil være omtrent fem ganger større ved en Mars-ferd. Noen høyrisikofunn, inklusive aktiverte DNA-reparasjonsgener og reduserte kognitive evner, varte hele observasjonsperioden på seks måneder etter avsluttet romferd.

- De relativt omfattende endringene i DNA som oppstod under romfarten, hvorav en del av dem vedvarte flere måneder etter hjemkomst, gir grunn til bekymring, sier Dag Undlien, som er professor i medisinsk genetikk ved Oslo universitetssykehus og Universitetet i Oslo. Genomisk instabilitet og nyoppståtte mutasjoner er kjennetegn ved kreftceller. Denne studien tyder på at den økte strålingen man blir utsatt for ved langvarig opphold i verdensrommet, vil øke risikoen for utvikling av kreft, sier Undlien.

\section{LITTERATUR:}

1. Garrett-Bakelman FE, Darshi M, Green SJ et al. The NASA Twins Study: A multidimensional analysis of a year-long human spaceflight. Science 2019;364:144-63. [PubMed]

Publisert: 2. oktober 2019. Tidsskr Nor Legeforen. DOI: 10.4045/tidsskr.19.0469

(C) Tidsskrift for Den norske legeforening 2020. Lastet ned fra tidsskriftet.no 